\title{
BOYS WILL BE . . .
}

\section{BY DAVID L. COWEN}

Professor Cowen is chairman of the History Department, University College

$7 \mathrm{HE}$ Rutgers undergraduate of forty-five years ago who regularly engaged in research at the library would rather

1 soon find himself confronted by no less a personage than the University Librarian. George Osborn's opening question was usually: "What are you working on now?" and the result was invariably the production of a plethora of materials and suggestions. Flattered by attention, armed with material, the student hardly realized the subtle influence at work upon him.

It was after such an encounter that $\mathrm{Mr}$. Osborn handed me the printed version of the Bogart Letters, ${ }^{1}$ a collection of letters written by or to John Bogart, a Queen's student who was graduated in 1778 .

The letters proved to be exactly what I was seeking for a paper on the social life of the time. But it was not long before I came running to $\mathrm{Mr}$. Osborn to ask to see the original letters. I pointed out to him that the printed collection contained certain asterisk-studded lacunae where material "characteristic of the time and place" had been deleted by the editor. Mr. Osborn joined me as we filled in the gaps, and my paper was peppered with references to hasty marriages, "unseasonable begotten children," and speculation as to why that old gentleman from Griggstown married a young wife.

The letter that most turned a young man's fancy, however, was one written by Simeon DeWitt, then a not quite twenty-year old student (later Geographer of the Revolutionary Army, Surveyor General of New York, and Chancellor of the University of the State of New York). Simeon's images had an intuitive flash of truth about them, and the cruelty of his fate struck a sympathetic chord. The letter follows:

\section{Dear Sir}

I have exchanged my obscure eastern corner for the sunny front of the house in order to receive the warmth of the solar rays these Raw windy days where

1 [D. D. Demarest, Ed.] The John Bogart Letters (New Brunswick, 1914). 
my thoughts are continually diverted and variously exchanged by the different objects that pass along the street and by the way I may remark that this perhaps is the reason of this wildness of Syle. However I sit at my window and observe the various movements below. but nothing more employs my attention than the pretty Girls. When I see a parcel of them pass by I immediately begin to reson with myself and compose syllogisms on them and sometimes indeed sophisms too Now I wish for the criticisms of Lad and then think of what Swift or Horace would have said upon meeting such a variety of appearances in the same Species. Some appearing like the picture of Mercury with wings to their heads their Elbows and so on others with their heads beat into conical spires whilst others again are flatted at top and have the Brim prominent over the nose which necessitates their heads to a graceful position in order to admit daylight to the Eyes Just so the turkey struts with the flabby skin upon his bill so the duck moves his tail. The other day I happened to cast my eye about and perceived a female form at a distance variegated with Silks and Lawns and gauze and near a Bushel of rufled stuf composed the superstructure. The least motion of her body discovered some affected gracefulness \& I know not how indicated a consciousness of superior merit and excellence I admired her to be sure. Upon second consideration I determined to take a nearer View I accordingly advanced toward the heavenly Object \& would have come within a few feet of her had I not been suddenly stopped by her turning toward me a whole broad side of her face, at once. I was struck with surprise. The first thing that presented itself was the meeting of her nose and Chin at half distances and a ghastly grin between at second glance her Eyes glared direct upon me like the reflection of light from two opague balls of glass her cheeks were drawn outwards and her forehead gathered into wrinkles I turned About and went to my 
room and composed this letter which is now finished $\&$ submitted to Your criticisms.

$$
\begin{aligned}
& \text { I am Dear Sir } \\
& \text { Yr } \\
& \text { sincere friend } \\
& \text { S D, Witt }
\end{aligned}
$$

October 2, 1776

New Brunswick

For John Bogart Student

How really universal was Simeon's experience, however, was pointed up by the publication in this Journal, in I945, of some letters of Washington Irving. ${ }^{2}$ A portion of one of these must certainly be placed in juxtaposition with Simeon's. Irving was twenty-one years old when it was written. ${ }^{3}$

My dear fellow

Bordeaux, July 20th, 1804

... As to the fair part of the community, I cannot say that they have as yet displayed charms sufficient to make me forget the sweet creatures I have left behind. However they are not to be blamed in this particular for they are by no means backward in displaying what charms they have. A sun beam falling on one of the Bordeaux bells, renders her perfectly transparent, and a slight zephyr betrays the contour of every limb, and the working of every muscle. In New York, formerly, ladies were allowed by the rules of modesty to show the foot, as a greater freedom of manners gained ground, they gradually raised the drapery till it reveald the ancle where they at present make a pause. The ladies of france however have more rapidly progressed in refinement, and without transgressing the rules of fashionable propriety, they generously display to the very garter. But I will say this

2 Clara Kirk and Rudolph Kirk, "Seven Letters of Washington Irving," The Journal of the Rutgers University Library, IX (1945) 1-22.

${ }^{3}$ The complete letter is to be found in Stanley T. Williams, The Life of Washington Irving (New York, 1935) Vol. 1 . The portion cited is on pp. 48-49. 
for them, whatever part of the body is forbid to be exhibited, it is very scrupulously and modestly shrouded from view by an impenetrable veil of fine muslin.

With such fascinating objects around me think what a warfare there is between the flesh and the spirit, and what dreadful conflicts I have with the 'divinity that stirs within me.' You cant imagine how many narrow escapes I have every day, from falling in love. How often in walking the street, do I see a fair nymph before me tripping along in airy movements. Her form of the greatest symetry, while the zephers are continually betraying:

c-the alluring line of grace

That leads the eye a wanton chase

And lets the fancy rove.'

I hurry after to catch a nearer view, to feast my eyes with the bright vision before its disappears. The sound of my steps calls her attention, she turns her face towards me-the charm is broken-and all my admiration \& enthusiasm is disapated. I see a wide mouth, small black eyes, cheeks highly rouged and hair greased with antient oil and twisted from the forehead to the chin till it resembles the head dress of a Medusa! . . .

\section{Your friend W. I.}

These letters are now submitted to the reader's criticism. If he wishes, he may follow Simeon's advice and compose syllogisms upon them, or perhaps even sophisms. Or perhaps he may just muse on his own times and customs. 